\title{
Paleomagnetic Susceptibility Distribution and Geochemical Analysis from the Eastern Part of Kalambaina Formation Sokoto Basin North West, Nigeria
}

\author{
Adamu Abubakar ${ }^{1}$, Faruk Usman ${ }^{2}$ and Musa M Zayyanu ${ }^{3}$ \\ ${ }^{1}$ Department of Applied Geophysics, Federal University Birnin Kebbi, Nigeria \\ ${ }^{2}$ Department of Pure \& Industrial Chemistry, Federal University Birnin Kebbi, Nigeria \\ ${ }^{3}$ National Centre for Technology Management, Ile-Ife, Osun State, Nigeria \\ Corresponding E-mail: adamu.abubakar35@fubk.edu.ng
}

Received 20-04-2021

Accepted for publication 14-05-2021

Published 21-05-2021

\begin{abstract}
Magnetic measurements, mineralogical and geochemical studies were carried out on surface soil samples in order to delineate susceptibility distribution and to find possible relationships based on paleomagnetic implications in some part of Kalambaina Area of Sokoto Northwestern Nigeria. Geomorphologically, this area is generally gentle, with occasionally tabular, capped by resistance laterites. Elevation generally decreases towards the northwest around the Nigeria - Niger Republic boarder with an average elevation of about $215 \mathrm{~m}$ above mean sea level. A total of 90 sample were measured at random with DSM-10 susceptibility Kappa metre as well 20 core drilling samples were collected for further XRF geochemical analysis. Mass specific susceptibility value ranges between $11.2 \times 10^{-6}$ SI and $1.4-8.2 \times 10^{-6}$ SI and magnetic remanence at $1 \mathrm{~T}$ values range between $10 \times 10^{-6} \mathrm{SI}$ and $0.5-9.0 \times 10^{-6} \mathrm{SI}$ as well as $0.5-$ $7.4 \times 10^{-6} S I$. Chemical analysis by Xray Fluorescence analysis revealed the presence concentration of various elements with their percentage composition (\%) and the percentage composition of calcium carbonate $\left(\mathrm{CaCO}_{3}\right)$ content between $>40 \%$ and $<70 \%,>70 \%$ and $<80 \%$, core drilling depth and overburden thickness of a limestone Layer and Overburden. Has also revealed low- and high-grade calcium carbonate $\mathrm{CaCO}_{3}$ content.
\end{abstract}

Keywords: Paleomagnetic; Susceptibility Measurement; Geochemical Analysis; Soil Samples; Kalambaina Formation

\section{INTRODUCTION}

$\mathrm{T}$ he Kalambaina Formation consists of a white marine, clayey limestone and shale. The Type Section of the Formation is at the quarry of the cement factory of Northern Nigeria, near the village of Kalambaina, located about $6 \mathrm{~km}$ to the south-west of Sokoto township. The thickness of the Formation is quite variable, because of the subsurface dissolution of the limestone. The maximum thickness, recorded from the boreholes, is over $20 \mathrm{~m}$, but usually only about $12 \mathrm{~m}$ of section is exposed at the quarry. Near the village of Dange, the Kalambaina Formation is reduced to about $5 \mathrm{~m}$, but at Birnin Kebbi, further south, the Formation is approximately $18 \mathrm{~m}$ thick. The Formation is rich invertebrate fossils; mainly echinoids, corals, nautilus, and gastropods have also been described from the formation [1-4]. 
In the last 30 years, a growing number of studies using the techniques of magnetism of rocks has been applied to environmental problems, thus creating a new branch of research commonly called "environmental magnetism" [5]. This methodology is fast, economic and can be applied in various research fields, such as environmental monitoring, pedology, paleoclimatology, limnology, archeology and stratigraphy. Recent studies have demonstrated the advantages and the potential of the environmental magnetism methods as valuable aids in the detection and delimitation of areas affected by pollution [6-10].

One parameter often used in environmental magnetism studies is the magnetic susceptibility. This parameter is easy to measure and does not involve the destruction of the sample, therefore, left available for additional analyses. The measurement of the magnetic susceptibility of the surface soil layers has been used as a proxy to contamination from different pollution sources, diffuse and stationary [11-12]. Establishing a link between the concentration (and characteristics) of ferrimagnetic minerals and the heavy metal contents has been a challenge for a number of authors [13]. Magnetic parameters measured in soil profiles provide information that allows us to establish a limit in depth indicating the transition from the "polluted" to the deeper, "unpolluted" zone in contaminated natural soil [8].

Magnetic methods should be considered as a first choice and an appropriate strategy when conducting surveys [8] and they can be a helpful indicator when targeting and selecting sampling sites for subsequent geochemical analyses. These methods allow us to target the area most affected by pollution near roads and highways or industrial units, such as steel smelters [14-17], power plants [18-20] and cement plants [21]. These are the preferred areas for sampling in order to investigate the level of contamination by toxic elements like heavy metals, with consequent benefits in saving time, manpower and materials. Any protective and remedial actions will be applied more rationally when being restricted to these areas. In addition to the studies mentioned above, which can be described as the classic use of environmental magnetism with the aim to quantify pollution levels in air, sediments and soils, some authors have been concerned with the standardization of procedures and compatibility of instruments used in previous research [22]. This study attempt to (1) measure the In-situ magnetic parameters of various rocks, such as delineation of magnetic susceptibility $(\chi)$ distribution, hence the concentration of Fe-bearing mineral (2) Identify magnetic minerals responsible for the Magnetization (3) study the magnetic parameters, the chemical contents and the mineralogical composition in order to characterize the soil; and (4) to find possible relationships between the measured parameters.

\section{LOCATION AND ACCESSIBILITY OF THE STUDY AREA}

The study area lies between latitudes $13^{\circ} 03.83^{\prime} N-13^{\circ} 03.748^{\prime} N$ and longitudes $5^{\circ} 10.398^{\prime} E-5^{\circ} 10.745^{\prime} E$ in Northwestern part of Nigeria. The study area covered about $59570 \mathrm{~km}^{2}$ and is easily accessible through network of roads. Geomorphologically, this area is generally gentle, with occasionally tabular hills, capped by resistant laterites. Elevation generally decreases towards the northwest around the Nigeria - Niger Republic boarder with an average elevation of about $215 \mathrm{~m}$ above mean sea level.

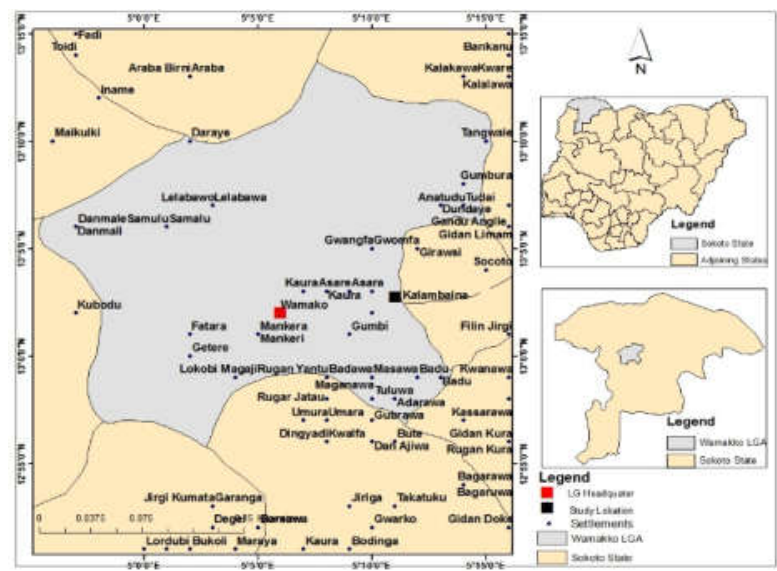

Fig. 1 Location Map of the Study Area (Adopted from Google Earth, 2019)

\section{TeCtonic SETting AND GeOlogy OF THE StUdy AREA}

The Sokoto Basin of northwestern Nigeria consists predominantly of a gentle undulating plain with an average elevation varying from $250-400 \mathrm{~m}$ above sea level. This monotonous plain is occasionally interrupted by steep-sided, flat-topped hills. A low escarpment, which was named as the "Dange Scarp" by earlier workers, is the most prominent feature in the basin, and is closely related to the geology (Fig. 2 ). The area to the east of this escarpment consists of predominantly of a gentle undulating, sandy plain, which extends southwestwards to the Basement Complex boundary. The escarpment itself has undergone intensive erosion. The edge is marked with a high drainage density indicating active stream dissection resulting in deeply incised ravines with numerous mesas and outliers scattered on the plains to the east [23]. In northwestern Nigeria the sediments of the Iullemmeden Basin were deposited during three main phases of deposition: continental Mesozoic and Tertiary phases, with an intervening marine Maastrichtian to Paleocene phase (Fig. 2). Overlying the Pre-Cambrian basement unconformably, the Illo and Gundumi Formations, made up of grifts and clays, form part of the "Continental Intercalier" of West Africa. They are overlain unconformably by the Maastrichtian Rima Group, consisting of mudstones and friable sandstones (Taloka and Wurno Formations), separated by the fossiliferous shaly Dukamaje Formation. The Paleocene Dange and Gamba Formations (mainly shales) are separated by calcareous Kalambaina Formation. The overlying continental Gwandu 
Formation (Continental Terminal) is of Tertiary age. These sediments dip gently and thicken gradually towards the northwest, with a maximum thickness of over $1000 \mathrm{~m}$ near the frontier of the Niger Republic [2].

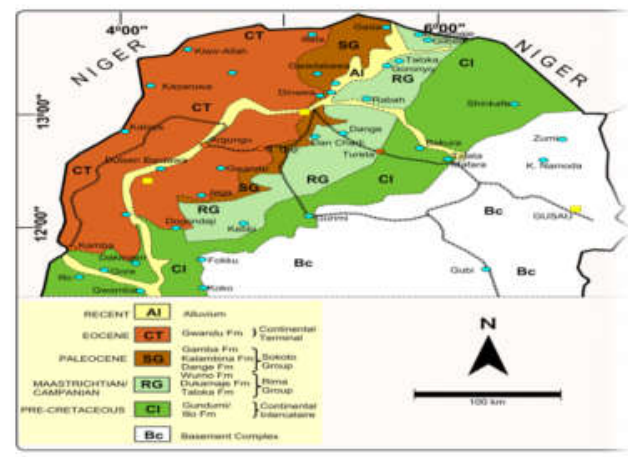

Fig. 2 Generalized Geological Map of the Sokoto Basin [3]

\section{MATERIALS AND METHODS}

\section{A. Site Description, Field work and Soil Sampling}

The study area (Fig. 1) is located in Sokoto Basin northwestern Nigeria near the eastern part of Kalambaina area. The climate of the area immediately south of Sahara (that is including the Rima Basin), was becoming drier and desert conditions were spreading southward. Mean annual precipitation is around $650 \mathrm{~mm}$ and mean annual temperature is $36^{\circ} \mathrm{C}$. Prevailing wind direction is $\mathrm{SE}$ in November, December, January and February and NW in the remaining months. Sandstones and lime stones are the dominant lithologies. This area is mainly occupied by the alluvial plain of the Goronyo River with numerous agricultural fields and drainage channels; it is also crossed by motorable road, which connects the cities of Gada and Goronyo. Human presence in the area goes back over 2000 years [2]. Ninety samples (90) were randomly collected using a square grid of $500 \mathrm{~m} \times$ $500 \mathrm{~m}$, distributed across site 1, 2, and 3, as well as in other selected locations (Fig. 3). Soil material was sampled from the upper $0-20 \mathrm{~cm}$. For each sampling site, a composite sample of $1 \mathrm{~kg}$ was produced from four sub samples.

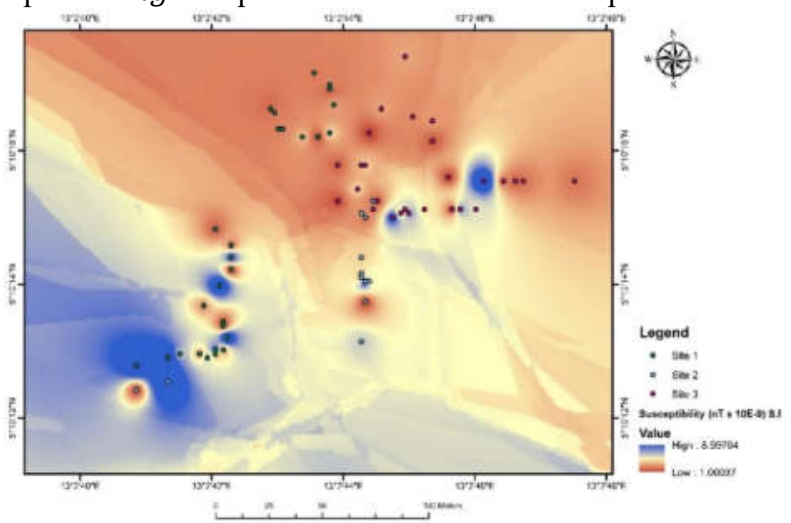

Fig. 3 Sampling Distribution Map of the Study Area

\section{B. Heavy Metal analysis}

In situ measurements of volume magnetic susceptibility $\kappa$ were made in a grid of $1.12 \mathrm{~km}^{2}$ using pocket GF Magnetic susceptibility meter DSM-10 making access to $90 \%$ of measuring signal e.g., concentration of ferrimagnetic material in the top $20 \mathrm{~mm}$ of the land surface with operating frequency of $10 \mathrm{kHz}$ and sensitivity of $1 \times 10^{-6} \mathrm{SI}$ units. In order to check reproducibility and to avoid measurement errors, each measurement was repeated three times and the mean accepted as the magnetic susceptibility (MS).

\section{Heavy Metal analysis}

The collected soil samples were ground in a mechanical agate grinder until fine particles $(<200 \mu \mathrm{m})$ were obtained. The prepared soil samples were analyzed for their heavy metal concentrations using acid digestion method [24]. About $0.250 \mathrm{~g}$ of the soil samples were weighed and placed into Pyrex test tubes. Concentrated nitric acid $(4.0 \mathrm{ml})$ and $1.0 \mathrm{ml}$ concentrated perchloric acid were added. The mixtures were heated in an aluminum block until complete dryness. After the test tubes were cool, $5 \%(0.8 M)$ nitric acid was added and heated at $60^{\circ} \mathrm{C}$ for $1 \mathrm{~h}$ with occasional mixing. Upon cooling, the mixtures were decanted into polyethylene tubes and centrifuged at $3500 \mathrm{rpm}$ for $10 \mathrm{~min}$. Heavy metal concentrations of the solutions were measured using X-ray Fluorescent Diffractor meter (XRF-D).

\section{RESULTS AND DISCUSSION}

\section{A. Soil Magnetic Susceptibility Spatial Distribution}

Magnetic susceptibility values are about $11.2 \times 10^{-6} \mathrm{SI}$, ranging from $1.4-8.2 \times 10^{-6} S I$ in Site 1 and about $10 \times 10^{-6} S I$, ranging from $0.5-9.0 \times 10^{-6} S I$ in Site 2 . Site 2 shows enhancement of magnetic susceptibility distribution compared to the Site 1 which is far away from the quarry site in Kalambaina Katare. The highest values of topsoil susceptibility are recorded in Site 1 with variations of two to three orders of magnitude compared to the values recorded in Site 3. For comparison with value found in Gatere urban topsoil $\left(0.5 \times 10^{-6}-7.4 \times 10^{-6} S I\right)$ [25], the mean value in the lateritic topsoil is lower. In order to highlight and delineate the trends of MS a contour map was plotted to delineate each distribution across site 1,2, and 3. Fig. 4, 5 and 6 show the spatial map distributions of site 1,2 and 3 respectively. Magnetic susceptibility shows inhomogeneous repartition with probable zones of anomalies peaks at site 3 . In site 2, magnetic distribution is slightly homogeneous with a standard value ranging from $0.5 \times 10^{-6}-9.0 \times 10^{-6} \mathrm{SI}$. The relatively high magnetic susceptibility values suggested that the soil was enriched with ferrimagnetic grains probably as a consequence of ferruginous sandstone iron deposit. In site 1 , Lower susceptibility values were found and distributed widely in all prospected surface topsoil. In respect to the same physical characteristic of soil in both sites and remoteness to the road edge, lower magnetic susceptibility values were also 
found in site 3 which suggest the soil is not affected by remanent magnetization.

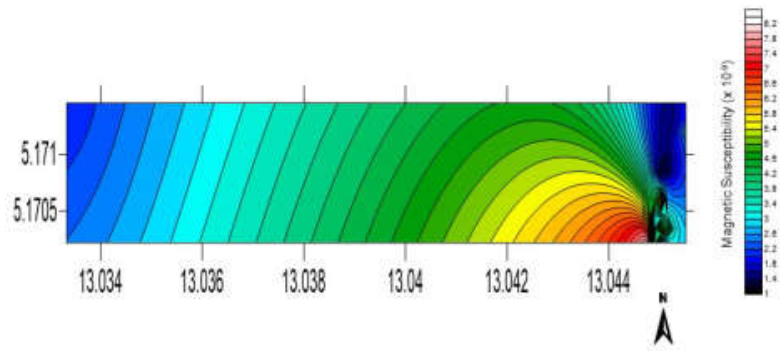

Fig. 4 Spatial Distribution Map of Magnetic Susceptibility at Site 1 .
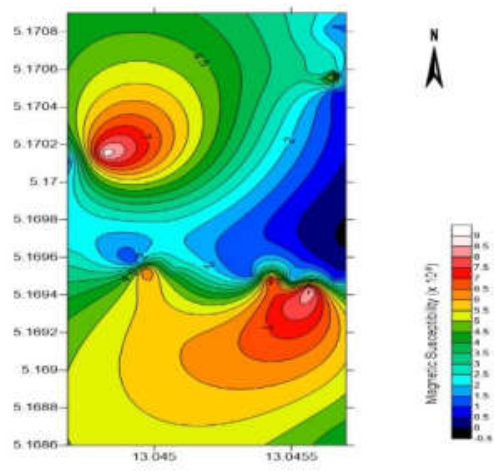

Fig. 5 Spatial Distribution Map of Magnetic Susceptibility at Site 2 .

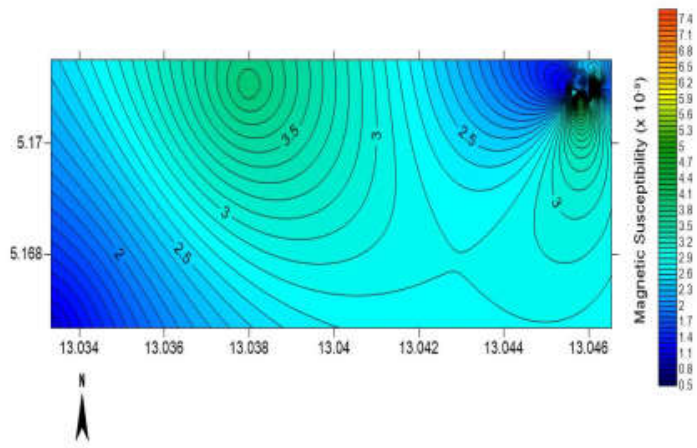

Fig. 6 Spatial Distribution Map of Magnetic Susceptibility at Site 3

B. Magnetic Susceptibility Distribution Mapping Across the Areas

A positive and reliable relation of magnetic susceptibility with the total content of heavy metals allows us to perform a detailed survey of urban areas, highlighting areas with increased soil magnetic iron, $\mathrm{Fe}$ bearing content [25]. In site 1 , the volume of magnetic susceptibility ranged from $1.6 \times$ $10^{-6}-11.8 \times 10^{-6} S I$. Within the same area, the total content of cobalt varied from $1.5-12.6$, that of arsenic from $0.5-6.8$, and copper from $6-62 \mathrm{mg} / \mathrm{kg}$. On the tables, contamination by these heavy elements is found to be consistent with magnetic minerals of soils (through magnetic susceptibility) and relate to the concentrations of mineralogical composition (see Table 1, 2 \& 3). Mapping of the magnetic susceptibility enables a detailed assessment of soil contamination with heavy metals over a large area (Fig. 7).

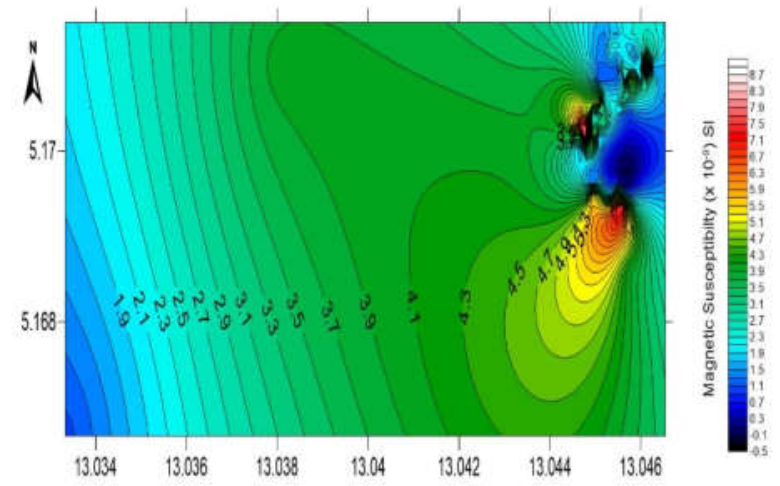

Fig. 7 Spatial Distribution Map of Magnetic Susceptibility across Site 1, 2 \& 3

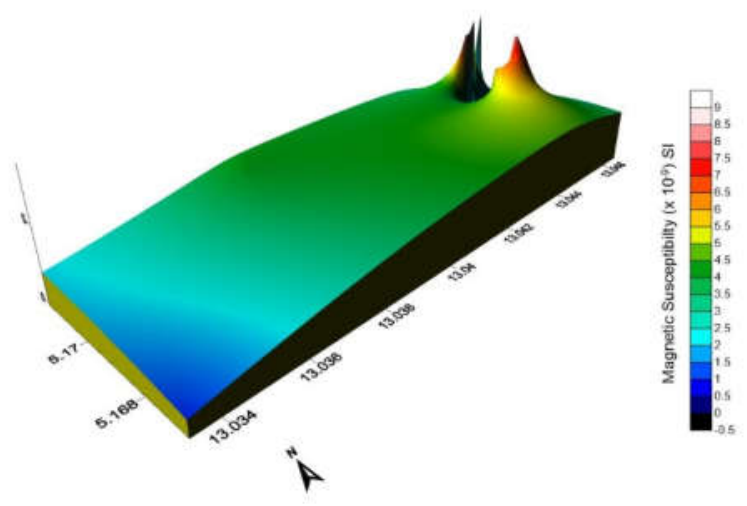

Fig. 8 3D Isometric View of Magnetic Susceptibility Distribution Map of the Study Area

\section{Geochemical Analysis}

The XRD analysis (Table 1, $2 \& 3$ ) shows that the mineral suites consist mainly of Manganese oxide $(\mathrm{MnO})$, Silicates Oxide $\left(\mathrm{SiO}_{2}\right)$, k-feldspars $\left(\mathrm{K}_{2} \mathrm{O}\right)$, Sodium Oxide $\left(\mathrm{Na}_{2} \mathrm{O}\right)$, Calcium Oxide $(\mathrm{CaO})$, Hematite $\left(\mathrm{Fe}_{2} \mathrm{O}_{3}\right)$, Aluminium Oxide $\left(\mathrm{Al}_{2} \mathrm{O}_{3}\right)$, Lead Oxide $(\mathrm{PbO})$, Maghemite $(\mathrm{MgO})$, Titanium 
Oxide $\left(\mathrm{TiO}_{2}\right)$ and Calcium Carbonate $\left(\mathrm{CaCO}_{3}\right)$. Some samples have low quantities of magnetite/ maghemite $(<$ $3 \%$ ). This result corroborates with the findings of other authors $[15,26]$. Other samples showed traces of Calcium carbonate and Hematite. Hematite and Manganese have been found in several locations as a secondary mineral deposit within the study area [27-28]. In this study, we consider that the existence of this mineral which is probably related with Sokoto cement mining site upstream of Kalambaina formation in the village of Katere, Gatere, near Wamako [29]. The spatial variation of the core-drilled values of Katere site 1 , Gatere site 2 and Quarry Kalambaina site 3 in soil profile shown in (Fig. 9, $10 \& 11$ ). The core values of soils from Katere site 1, representing the higher level of soil thickness, ranged from $(1.6-3.55 \mathrm{~m})$ across the study area. Low enhancement of overburden thickness of $(0.9-3.05 \mathrm{~m})$ in Quarry Kalambaina site 3, could be reported to the process of soil formation in the area of study. Spatial variation plot of (Fig. 10) revealed the slight increase in alluvium overburden thickness $(1.49-2.76 \mathrm{~m})$ in its surface horizon and steeply decrease from upper horizon $(0.57-1.9 \mathrm{~m})$, thus suggesting to contribution of anthropogenic origin. The clay fraction of the analysed soils is characterized by a rather uniform clay mineral assemblage. The XRD analysis shows that silicates mineral (average $28.90 \%$ ), kaolinite (average $1.5 \%$ ), calcite (average $38 \%$ ) and irregular Hematite-magnetite mixed layers (average $6.82 \%$ ) and Calcium carbonate $\mathrm{CaCO}_{3}$ (average $69.26 \%$ ) are the major clay mineral groups identified. These results are similar to the clay mineral suite observed in the quarry site of Sokoto cement company [2]. No significant correlations are found between clay mineralogy and the magnetic data. Correlations between $\mathrm{R}$ index (calculated for the main clay minerals) and the magnetic parameters show significant correlation between core drilling depth ( $\mathrm{R}$ calculated for limestone layer) and Overburden thickness (the correlation is negative but significant at the $8.43 \mathrm{~m}$ level), between magnetic susceptibility distribution parameters (R calculated for Aluminium oxide $\mathrm{Al}_{2} \mathrm{O}_{3}$. These correlations are significant at $<0.05$ level (Table 2). Correlations between $\mathrm{R}$ index and heavy metals show significant correlation between core drill and Concentration content, and between $\mathrm{CaCO}_{3}$ content (correlations are significant at 0.05 level and at 0.01 level, respectively) (Table 1). The degree of crystallinity has an important bearing on the scavenging of heavy metals by secondary minerals (such as clay minerals, sulfites, sulphates oxides and hydroxides) as poorly crystallized minerals are more efficient sorbents than crystalline ones. In particular, maghemite crystallochemical characteristics show good correlations with the distribution of some metals, pointing to a role of this mineral (in particular, under specific crystallochemical conditions) in their fixation. Actually, the order/disorder degree of their crystallographic structures and the type of octahedral composition $\left(\mathrm{Al}_{2} \mathrm{O}_{3}\right.$ rich versus $\mathrm{Fe}-\mathrm{Mg}$ rich) of the magnetite exert important control on the metal fixation.

TABLE 1. MINERAL COMPOSITION OF SOILS SAMPLES ANALYSIS BY XRD OF SITE 1, HEIDELBERG TECHNOLOGY CENTRE, GERMANY.

\begin{tabular}{|l|c|c|c|c|c|c|c|c|c|c|c|c|c|}
\hline $\begin{array}{c}\mathrm{LOI} \\
1050^{\circ} \mathrm{C} \\
\%\end{array}$ & $\begin{array}{c}\mathrm{SiO}_{2} \\
\%\end{array}$ & $\begin{array}{c}\mathrm{Al}_{2} \mathrm{O}_{3} \\
\%\end{array}$ & $\begin{array}{c}\mathrm{TiO}_{2} \\
\%\end{array}$ & $\begin{array}{c}\mathrm{MnO}_{2} \\
\%\end{array}$ & $\begin{array}{c}\mathrm{F}_{2} \mathrm{O}_{3} \\
\%\end{array}$ & $\begin{array}{c}\mathrm{CaO} \\
\%\end{array}$ & $\begin{array}{c}\mathrm{MgO} \\
\%\end{array}$ & $\begin{array}{c}\mathrm{K}_{2} \mathrm{O} \\
\%\end{array}$ & $\begin{array}{c}\mathrm{Na}_{2} \mathrm{O} \\
\%\end{array}$ & $\begin{array}{c}\mathrm{SO}_{3} \\
\%\end{array}$ & $\begin{array}{c}\mathrm{P}_{2} \mathrm{O}_{5} \\
\%\end{array}$ & $\begin{array}{c}\mathrm{Total} \\
\%\end{array}$ & $\begin{array}{c}\mathrm{CaCO}_{3} \\
\%\end{array}$ \\
\hline 21.12 & 46.40 & 11.50 & 0.71 & 0.15 & 7.49 & 7.99 & 3.94 & 0.38 & $<0.01$ & $<0.01$ & 0.28 & 99.96 & 14.26 \\
\hline 27.90 & 32.30 & 9.20 & 0.47 & 0.23 & 5.06 & 20.40 & 3.50 & 0.27 & $<0.01$ & $<0.01$ & 0.58 & 99.91 & 36.41 \\
\hline 28.46 & 28.90 & 8.06 & 0.42 & 0.21 & 6.82 & 22.80 & 2.95 & 0.32 & $<0.01$ & $<0.01$ & 0.75 & 99.69 & 40.70 \\
\hline 36.07 & 15.40 & 4.30 & 0.23 & 0.05 & 2.91 & 38.80 & 1.71 & 0.19 & $<0.01$ & $<0.01$ & 0.22 & 99.88 & 69.26 \\
\hline 38.59 & 11.20 & 3.02 & 0.15 & 0.02 & 1.35 & 43.90 & 1.39 & 0.14 & $<0.01$ & $<0.01$ & 0.10 & 99.86 & 78.36 \\
\hline 38.83 & 11.00 & 2.66 & 0.14 & 0.02 & 1.20 & 44.00 & 1.54 & 0.14 & $<0.01$ & $<0.01$ & 0.12 & 99.65 & 78.54 \\
\hline 41.65 & 4.20 & 1.05 & 0.05 & 0.03 & 0.84 & 51.10 & 0.71 & 0.05 & $<0.01$ & $<0.01$ & 0.13 & 99.90 & 91.21 \\
\hline 43.16 & 1.36 & 0.22 & 0.01 & 0.05 & 0.33 & 54.30 & 0.44 & 0.02 & $<0.01$ & $<0.01$ & 0.04 & 99.93 & 96.93 \\
\hline 35.16 & 18.30 & 5.03 & 0.25 & 0.04 & 2.29 & 34.90 & 2.51 & 0.30 & $<0.01$ & $<0.01$ & 0.12 & 98.90 & 62.30 \\
\hline
\end{tabular}

TABLE 2. MINERAL COMPOSITION OF SOILS SAMPLES ANALYSIS BY XRD OF SITE 2, HEIDELBERG TECHNOLOGY CENTRE, GERMANY.

\begin{tabular}{|c|c|c|c|c|c|c|c|c|c|c|c|c|c|}
\hline $\begin{array}{c}\mathrm{LOI} \\
1050{ }^{\circ} \mathrm{C}\end{array}$ & $\begin{array}{c}\mathrm{SiO}_{2} \\
\%\end{array}$ & $\begin{array}{c}\mathrm{Al}_{2} \mathrm{O}_{3} \\
\%\end{array}$ & $\begin{array}{c}\mathrm{TiO}_{2} \\
\%\end{array}$ & $\begin{array}{c}\mathrm{MnO}_{2} \\
\%\end{array}$ & $\begin{array}{c}\mathrm{Fe}_{2} \mathrm{O}_{3} \\
\%\end{array}$ & $\begin{array}{c}\mathrm{CaO} \\
\%\end{array}$ & $\begin{array}{c}\mathrm{MgO} \\
\%\end{array}$ & $\begin{array}{c}\mathrm{K}_{2} \mathrm{O} \\
\%\end{array}$ & $\begin{array}{c}\mathrm{Na}_{2} \mathrm{O} \\
\%\end{array}$ & $\begin{array}{c}\mathrm{SO}_{3} \\
\%\end{array}$ & $\begin{array}{c}\mathrm{P}_{2} \mathrm{O}_{5} \\
\%\end{array}$ & $\begin{array}{c}\mathrm{Total} \\
\%\end{array}$ & $\begin{array}{c}\mathrm{CaCO}_{3} \\
\%\end{array}$ \\
\hline 27.90 & 32.30 & 9.20 & 0.47 & 0.23 & 5.06 & 20.40 & 3.50 & 0.27 & $<0.01$ & $<0.01$ & 0.58 & 99.91 & 36.41 \\
\hline 34.79 & 16.10 & 4.57 & 0.23 & 0.11 & 4.55 & 36.90 & 1.78 & 0.19 & $<0.01$ & $<0.01$ & 0.74 & 99.96 & 65.87 \\
\hline 24.79 & 34.00 & 11.70 & 0.59 & 0.19 & 7.77 & 16.20 & 2.73 & 0.47 & $<0.01$ & $<0.01$ & 1.33 & 99.77 & 28.92 \\
\hline 36.42 & 14.60 & 4.07 & 0.21 & 0.03 & 2.86 & 39.30 & 1.79 & 0.19 & $<0.01$ & $<0.01$ & 0.27 & 99.74 & 70.15 \\
\hline 35.84 & 16.90 & 4.34 & 0.22 & 0.03 & 1.95 & 37.50 & 2.29 & 0.22 & $<0.01$ & $<0.01$ & 0.22 & 99.51 & 66.94 \\
\hline 43.40 & 0.91 & 0.16 & 0.01 & 0.03 & 0.29 & 54.70 & 0.38 & 0.01 & $<0.01$ & $<0.01$ & 0.06 & 99.95 & 97.64 \\
\hline 42.95 & 1.48 & 0.34 & 0.02 & 0.05 & 0.42 & 54.20 & 0.37 & 0.03 & $<0.01$ & $<0.01$ & 0.06 & 99.93 & 96.75 \\
\hline 35.08 & 18.80 & 5.05 & 0.26 & 0.05 & 2.52 & 35.10 & 2.58 & 0.31 & $<0.01$ & $<0.01$ & 0.14 & 99.89 & 62.65 \\
\hline
\end{tabular}

TABLE 3. MINERAL COMPOSITION OF SOILS SAMPLES ANALYSIS BY XRD OF SITE 3, HEIDELBERG TECHNOLOGY CENTRE, GERMANY.

\begin{tabular}{|c|c|c|c|c|c|c|c|c|c|c|c|c|c|}
\hline $\begin{array}{c}\mathrm{LOI} \\
1050^{\circ} \mathrm{C} \\
\%\end{array}$ & $\begin{array}{c}\mathrm{SiO}_{2} \\
\%\end{array}$ & $\begin{array}{c}\mathrm{Al}_{2} \mathrm{O}_{3} \\
\%\end{array}$ & $\begin{array}{c}\mathrm{TiO}_{2} \\
\%\end{array}$ & $\begin{array}{c}\mathrm{MnO}_{2} \\
\%\end{array}$ & $\begin{array}{c}\mathrm{Fe}_{2} \mathrm{O}_{3} \\
\%\end{array}$ & $\begin{array}{c}\mathrm{CaO} \\
\%\end{array}$ & $\begin{array}{c}\mathrm{MgO} \\
\%\end{array}$ & $\begin{array}{c}\mathrm{K}_{2} \mathrm{O} \\
\%\end{array}$ & $\begin{array}{c}\mathrm{Na}_{2} \mathrm{O} \\
\%\end{array}$ & $\begin{array}{c}\mathrm{SO}_{3} \\
\%\end{array}$ & $\begin{array}{c}\mathrm{P}_{2} \mathrm{O}_{5} \\
\%\end{array}$ & $\begin{array}{c}\mathrm{Tota}^{2} \\
\%\end{array}$ & $\begin{array}{c}\mathrm{CaCO}_{3} \\
\%\end{array}$ \\
\hline 26.49 & 36.00 & 9.24 & 0.53 & 0.13 & 4.21 & 18.20 & 4.05 & 0.43 & $<0.01$ & $<0.01$ & 0.43 & 99.71 & 32.49 \\
\hline 39.86 & 8.54 & 2.15 & 0.11 & 0.03 & 0.98 & 46.60 & 1.34 & 0.10 & $<0.01$ & $<0.01$ & 0.12 & 99.83 & 83.18 \\
\hline 36.78 & 14.70 & 4.07 & 0.22 & 0.03 & 1.61 & 40.10 & 1.68 & 0.21 & $<0.01$ & $<0.01$ & 0.18 & 99.58 & 71.58 \\
\hline
\end{tabular}

TABLE 4(a). CORE DRILL LOG DATA OF SOILS OF SITE 1, HEIDELBERG TECHNOLOGY CENTRE, GERMANY.

\begin{tabular}{|c|c|c|c|c|c|c|c|}
\hline \multirow{4}{*}{ Limestone Layer } & & \multicolumn{2}{|c|}{ Drilling Depth } & \multicolumn{2}{|c|}{ Elevation } & \multicolumn{2}{|c|}{ Thickness } \\
\hline & & From & To & $\begin{array}{l}\text { From } \\
\text { maSL }\end{array}$ & $\begin{array}{l}\text { To } \\
\text { maSL }\end{array}$ & $\mathrm{m}$ & $\mathrm{m}$ \\
\hline & Low Grade & 8.43 & 13.50 & 267.33 & 262.26 & 5.07 & \\
\hline & High Grade & 13.50 & 18.50 & 262.26 & 257.26 & 5.00 & 10.07 \\
\hline Overburden & & 0.00 & 8.43 & 275.78 & 267.33 & & \\
\hline
\end{tabular}


TABLE 4(b). CORE DRILL LOG DATA OF SOILS OF SITE 2, HEIDELBERG TECHNOLOGY CENTRE, GERMANY.

\begin{tabular}{|c|c|c|c|c|c|c|c|}
\hline \multirow{4}{*}{ Limestone Layer } & & \multicolumn{2}{|c|}{ Drilling Depth } & \multicolumn{2}{|c|}{ Elevation } & \multicolumn{2}{|c|}{ Thickness } \\
\hline & & From & To & $\begin{array}{l}\text { From } \\
\text { maSL }\end{array}$ & $\begin{array}{l}\text { To } \\
\text { maSL }\end{array}$ & $\mathrm{m}$ & $\mathrm{m}$ \\
\hline & Low Grade & 14.38 & 17.10 & 263.61 & 260.89 & 2.72 & \\
\hline & High Grade & 17.10 & 21.76 & 260.89 & 256.23 & 4.65 & 7.38 \\
\hline Overburden & & 0.00 & 14.38 & 277.99 & 263.61 & & \\
\hline
\end{tabular}

TABLE 4(c). CORE DRILL LOG DATA OF SOILS OF SITE 3, HEIDELBERG TECHNOLOGY CENTRE, GERMANY.

\begin{tabular}{|c|c|c|c|c|c|c|c|}
\hline \multirow{4}{*}{ Limestone Layer } & & \multicolumn{2}{|c|}{ Drilling Depth } & \multicolumn{2}{|c|}{ Elevation } & \multicolumn{2}{|c|}{ Thickness } \\
\hline & & From & To & $\begin{array}{l}\text { From } \\
\text { maSL }\end{array}$ & $\begin{array}{l}\text { To } \\
\text { maSL }\end{array}$ & $m$ & $m$ \\
\hline & Low Grade & 18.00 & 20.20 & 264.15 & 261.95 & 2.20 & \\
\hline & High Grade & 17.10 & 18.00 & 265.05 & 264.15 & 0.90 & 3.10 \\
\hline Overburden & & 0.00 & 17.10 & 282.15 & 265.05 & & \\
\hline
\end{tabular}

\section{Katere_Core Drilled Log, Site 1}

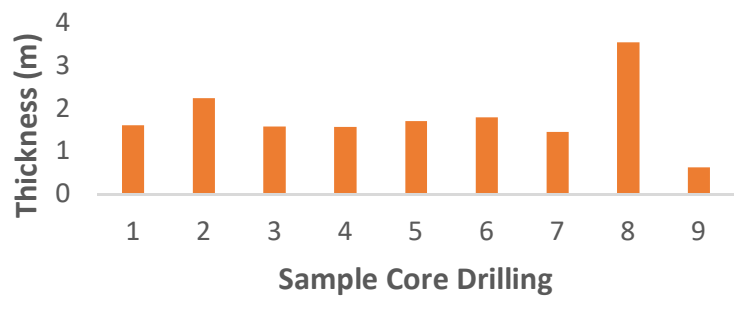

Fig. 9 Spatial distribution of Core-drilled $\log$ of Site 1 in Katere Kalambaina.

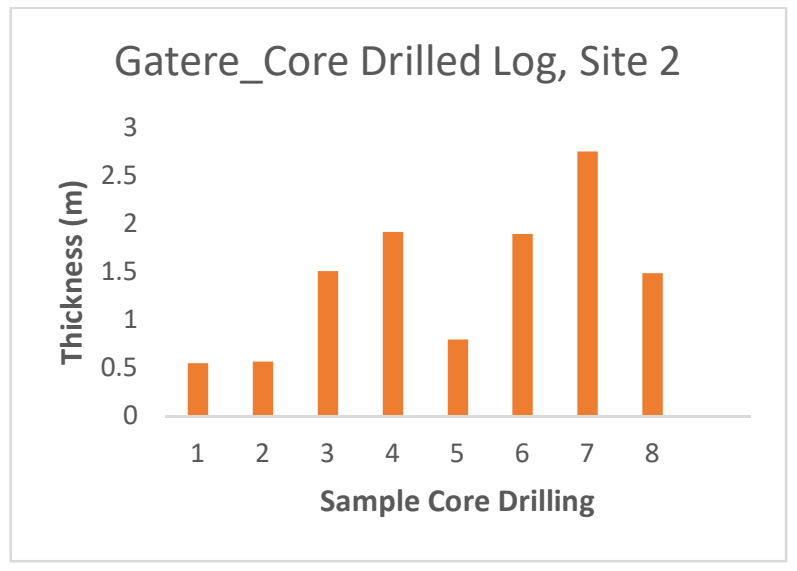

Fig. 10 Spatial distribution of Core-drilled log of Site 2 in Gatere Kalambaina.

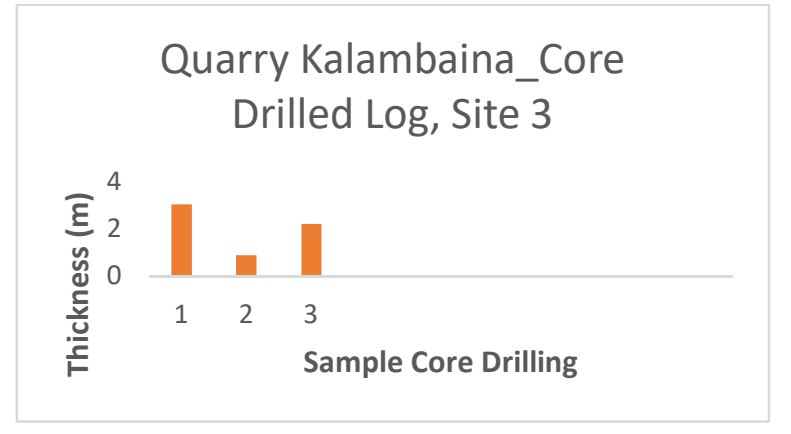

Fig. 11 Spatial distribution of Core-drilled log of Site 3 in Quarry Kalambaina.

\section{CONCLUSION}

Spatial variation of magnetic susceptibility shows a characteristic distribution with higher values near the quarry of Northern Sokoto Cement. Near the quarry, these values are associated with ferromagnetic material produced by industrial pollution. The analysis of in-situ magnetic susceptibility distribution acquisition spatial plot suggests that the main magnetic phases present in the samples are ferrimagnetic structures (e.g. magnetite/maghemite). Results obtained demonstrated that magnetic susceptibility distribution has a good correlation with heavy metals so this parameter can be used as a proxy for soil pollution; however, remanent magnetic parameters are better indicators for heavy metal pollutions than magnetic susceptibility in studied area [30]. The results of XRD analyses show that the most abundant minerals are Hematite, Manganese, Lead oxide, plagioclases, calcite and dolomite. They also confirm the presence of magnetite/maghemite although with a concentration generally below $2 \%$. Some samples shown traces of calcium carbonate. The new calculated index, $\mathrm{R}$, showed good correlation with magnetic parameters and with $\mathrm{MgO}$ and $\mathrm{SiO}_{2}$ contents. This study revealed that magnetic mapping is a sensitive, fast and robust method, which can be advantageously applied to regions affected by urban and industrial pollution.

\section{References}

[1] R. A. Reyment, "Aspect of the Geology of Nigeria". Ibadan University Press, pp. 133, 18 plates. 1965.

[2] C. A. Kogbe, "Geology of the Northwestern Nigeria Basin (a review) (1974) Geology of Nigeria, Kogbe C.A. (Ed.) Elizabethan Pub. Co. 1978, pp. 331 - 338.

[3] C. A. Kogbe, Y. LE Calvez, K. Mehes, and N. Grekoff, "Microbiostratigraphy of Lower Tertiary Sediments from the Southeastern Flank of the Iullemmeden Basin (N.W. Nigeria)". Proc. Vth African Micropal. Coll. Addis Ababa and Revista Espanola de Micropaleontologia, 1972b, ser.7, no. 3, pp. $523-538$.

[4] S. Peters, "The Marine Maastrichtian and Paleocene Sediments (of northwestern Nigeria) - The Dukamaje Formation and the Sokoto Group". Geological Guide to Some Nigerian Cretaceous- 
Recent Localities: 7th African Micropal. Coll. IleIfe, Nigeria, 1976, pp. 75-87.

[5] R. Thompson., J. A. Bloemendal, J. Dearing, F. Oldfield, T. A. Rummery, J. C. Stober, and G. M. Turner, "Environmental Applications of Magnetic Measurements", Science, vol. 207, pp. 481486,1980 .

[6] L. Bityukova, R. Scholger, and M. Birke, "Magnetic susceptibility as indicator of environmental pollution of soils in Tallinn”, Phys. Chem. Earth, vol. 24, pp. 829-35, 1999.

[7] T. Boyko, R. Scholger, and H. Stanjek, "Topsoil magnetic susceptibility mapping as a tool for pollution monitoring: reputability of in situ measurements", J. Appl. Geophys., vol. 55, pp. 249259, 2004.

[8] U. Blaha, E. Appel, and H. Stanjek, "Determination of anthropogenic boundary depth in industrially polluted soil and semi quantification of heavy metal loads using magnetic susceptibility", Environ. Pollut., vol. 156, pp. 278-289, 2008.

[9] S. G. Lu, H. Y. Wang, and S. Q. Bai, "Heavy metal contents and magnetic susceptibility of soils along an urban-rural gradient in rapidly growing city of eastern China", Environ. Monit., vol. 155, pp. 91101, 2009. doi:10.1007/s10661-008-0420-5.

[10]D. Matysek, H. Raclavska, and K. Raclavsky, "Correlation Between Magnetic Susceptibility and Heavy Metal Concentrations in Forest Soils of the Eastern Czech Republic", J. Environ. Eng. Geophys., vol. 13, pp. 13-26, 2008.

[11] C. R. Gomes, J. Dias, L. Neves, A. Rocha, and E. Gomes, "Relationships between Magnetic properties and heavy metals in Nerium oleander leaves and soils (Viseu, Central Portugal)", Geochim. Cosmochim. Acta, 71, A340-A340, Suppl. S AUG. 2006.

[12] V. Hoffmann, M. Knab, and E. Appel, "Magnetic susceptibility mapping of roadside pollution", J. Geoch. Explor., vol. 6, no. 6, pp. 313-326, 1999.

[13] M. Hanesch, and R. Scholger, "Mapping of heavy metals loading in soils by means of magnetic susceptibility measurements", Environ. Geol., vol. 42, pp. 857-870, 2002.

[14]O. Durza, "Heavy metals contamination and magnetic susceptibility in soils around metallurgical plant", Phys. Chem. Earth., vol. 24, pp. 541-543, 1999.

[15] M. A. E. Chaparro, J. C. Bidigain, and A. M Sinito, "Magnetic study applied to different environments (soils and stream sediments) from relatively polluted area in Buenos Aires province, Argentina”, Environ. Geol., vol. 45, pp. 654-664, 2004.

[16] M. Hanesch, G. Maier, and R. Scholger, "Mapping heavy metal distribution by measuring the magnetic susceptibility of soils", J. Geophys., vol. 107, pp. 605-608, 2003.

[17] O. Rosowiecka and J. Nawrocki, "Assessment of soils pollution extent in surroundings of ironworks based on magnetic analysis", Stud. Geophys. Geod., vol. 54, pp. 185-194, 2010.

[18]Z. Strzyszcz, T. Magiera, and F. Heller, "The influence of industrial emissions on the magnetic susceptibility of soils in Upper Silesia”, Stud. Geophys. Geod., vol. 40, pp. 276-286, 1996.

[19]A. Kapicka, E. Petrovsky, S. Ustjak, and K. Machackova, "Proxy mapping of fly-ash pollution of soils around a coal-burning power plant: a case study in the Czech Republic", J. Geoch. Explor., vol. 66, pp. 291-297, 1999.

[20] L. Veneva, V. Hoffmann, D. Jordanova, N. Jordanova, and T. Fehr, "Rock magnetic, mineralogical and microstructural characterization of fly ashes from Bulgarian power plants and the nearby anthropogenic soils", Phys. Chem. Earth, vol. 29, pp. 1011-1023, 2004.

[21]B. J. Gołuchowska, "Some factors affecting an increase in magnetic susceptibility of cement dusts", J. Appl. Geophys., vol. 48, pp. 103-112, 2001.

[22] L. Schibler, T. Boyko, M. Ferdyn, B. Gajda, S. Holl, N. Jordanova, and W. Rosler, "Topsoil magnetic susceptibility mapping: Data reproducibility and compatibility, measurement strategy", Stud. Geophys. Geod., vol. 46, pp. 43-57, MAGPROX Team, 2002.

[23] C. A. Kogbe, "Geology of the Upper Cretaceous and Lower Tertiary Sediments of the Nigerian Sector of the Iullemmeden Basin (West Africa)", Geologische Runds-chau, vol. 62, no. 1, pp. 197-211, Stuttgart, 1972.

[24]X. Li and I. Thornton, "Arsenic, antimony and bismuth in soil and pasture herbage in some old metalliferous mining areas in England", Environ. Geoch. and Health, vol. 15, pp. 135-144, 1993.

[25] M. El Baghdadi, A. Barakat, M. Sajieddine and S. Nadem, "Heavy metal pollution and soil magnetic susceptibility in urban soil of Beni Mellal City (Morocco), Environ. Earth Sci., pp. 1-15, 2011. doi:10.1007/s12665-011-1215-5.

[26] Heidelberg Technology Centre Germany DATEN_GEO/Africa/Nigeria/CCNN_Sokoto/CoreSamples.xls. 2007.

[27] V. A. Sarma, and G. S. Murti, "Plumbogummite minerals in Indian soils, Geoderma, vol. 3, pp. 321$327,1970$.

[28] J. O. Nriagu, "Lead orthophosphates-IV Formation and stability in the environment", Geoch. Cosmochim. Acta, vol. 38, pp. 887-898, 1974.

[29] C. A. Kogbe, "Paleogeographic History of Nigeria from Albian Times. Geology of Nigeria, ed. Elizabethan Pub. Co., Lagos, 1976 pp. 237-252.

[30] Y. N Vodyanitskii and S. A. Shoba, "Magnetic Susceptibility as an Indicator of Heavy Metal Contamination of Urban Soils (Review)", Moscow University Soil Science Bulletin, vol. 70, no. 1, pp. 13 - 20, 2015. ISSN 0147 - 6874, Allerton Press, Inc. 